\title{
Long-term safety and effectiveness of tocilizumab in patients with rheumatoid arthritis and inadequate responses to csDMARDs and/or TNF inhibitors: an open-label study close to clinical practice
}

\author{
Vivian P. Bykerk ${ }^{1,2}$ - Andrew J. K. Östör ${ }^{3}$ - José Alvaro-Gracia ${ }^{4}$ - Karel Pavelka ${ }^{5}$ - José Andrés Román Ivorra ${ }^{6}$. \\ Michael T. Nurmohamed ${ }^{7} \cdot$ Yves Luder $^{8} \cdot$ Paris N. M. Sidiropoulos $^{9} \cdot$ Jenny Devenport ${ }^{9} \cdot$ Jean Sibilia $^{10}$
}

Received: 21 December 2018 / Revised: 7 March 2019 / Accepted: 26 March 2019 / Published online: 26 April 2019

(C) The Author(s) 2019

\begin{abstract}
Objective To assess the long-term safety, tolerability, and effectiveness of tocilizumab (TCZ) as monotherapy or in combination with conventional synthetic disease-modifying antirheumatic drugs (csDMARDs) in clinical practice in patients with moderate to severe rheumatoid arthritis (RA).

Methods Patients in the 24-week, open-label ACT-SURE study who had at least a moderate EULAR response by week 24 and were from a participating country were eligible for this long-term extension (LTE); the patients continued to receive TCZ $8 \mathrm{mg} / \mathrm{kg}$ intravenously every 4 weeks as monotherapy or in combination with $\geq 1$ csDMARD for up to an additional 108 weeks. The primary endpoint was the incidence of adverse events (AEs) and serious AEs (SAEs). Effectiveness endpoints included Disease Activity Score in 28 joints (DAS28) responses, American College of Rheumatology (ACR) responses, and patient-reported outcomes (PROs).

Results Of the 1102 patients who completed the core 24-week study, 934 participated in the LTE; the median exposure to TCZ was 64.3 weeks. From baseline to the end of the LTE, AEs and SAEs occurred in $90 \%$ and $9 \%$ of patients, respectively. The overall event rates $(95 \% \mathrm{CI})$ of AEs and SAEs were 406.5 per 100 patient-years (PY) $(395.5,417.8)$ and 8.8 per 100 PY $(7.3$, 10.6), respectively. Mean (SD) improvement in DAS28 was 4.12 (1.18), $P<0.0001$. The DAS28 remission rates, ACR response rates, and PRO scores were maintained during the LTE study.

Conclusion In clinical practice, TCZ as monotherapy or in combination with csDMARDs was safe, well tolerated, and efficacious in patients with moderate to severe RA.
\end{abstract}

Keywords Monotherapy $\cdot$ Rheumatoid arthritis $\cdot$ Safety $\cdot$ Tocilizumab

Electronic supplementary material The online version of this article (https://doi.org/10.1007/s10067-019-04535-z) contains supplementary material, which is available to authorized users.

Vivian P. Bykerk

bykerkv@hss.edu

1 Inflammatory Arthritis Center, Hospital for Special Surgery, 535 East 70th Street, New York, NY 10021, USA

2 Department of Rheumatology, Mount Sinai Hospital, Toronto, Ontario, Canada

3 Department of Rheumatology, Cabrini Medical Centre, Melbourne, Victoria, Australia

4 Rheumatology Service, Hospital General Universitario Gregorio Marañon, Universidad Complutense Madrid, Madrid, Spain
5 Institute of Rheumatology and Clinic of Rheumatology, Charles University, Prague, Czech Republic

6 Rheumatology Service, Division of Rheumatology, Hospital Universitario y Politécnico La Fe, Valencia, Spain

7 Jan van Breemen Research Institute, VU University Medical Center, Amsterdam, The Netherlands

8 F. Hoffmann-La Roche Ltd, Basel, Switzerland

9 Genentech, Inc., South San Francisco, CA, USA

10 Department of Rheumatology, CHU Hautepierre, Strasbourg, France 


\section{Introduction}

Rheumatoid arthritis (RA) is a chronic, progressive autoimmune disease characterized by inflammation of the synovium, which often results in irreversible joint damage if left untreated. Initial treatment involves conventional synthetic disease-modifying antirheumatic drugs (csDMARDs) such as methotrexate (MTX); if the response to csDMARDs is inadequate, the addition of a biologic or targeted synthetic DMARD is recommended $[1,2]$. However, approximately $30 \%$ to $40 \%$ of patients with RA have an inadequate response to csDMARDs and tumor necrosis factor inhibitors (TNFis) [3-5]. Furthermore, although biologics are recommended in combination with csDMARDs, approximately one-third of patients with RA receive biologics as monotherapy [6]. In addition to DMARDs, low-dose glucocorticoids (GCs) are commonly used to treat patients with moderate to severe RA or those experiencing flares $[1,2,7]$; however, chronic use of GCs has been linked to significant morbidity and increased mortality in patients with RA $[8,9]$.

Tocilizumab (TCZ), a humanized monoclonal antibody that blocks the interleukin (IL)-6 receptor-alpha, has been shown to be a safe and effective treatment for patients with early or established RA in randomized controlled trials, either as monotherapy or in combination with csDMARDs [10-20]. The long-term effectiveness and safety of TCZ have been established in multiple clinical trials [21-24], thus informing patient care decisions in clinical practice because patients with RA often receive prolonged treatment. However, these trials excluded patients with certain prior therapies; patients who have failed multiple therapies may have more severe disease and be at risk for more comorbid conditions. Studies that include patients with RA who more closely resemble those in clinical practice are needed to further assess the long-term effectiveness and safety of TCZ.

ACT-SURE was a phase IIIb, open-label, single-arm study that further evaluated the safety, tolerability, and effectiveness of TCZ in an RA population more typical of those in clinical practice settings. Patients with RA from 25 countries and 264 centers who had an inadequate response to csDMARDs and/ or TNFis $[25,26]$ were included. The long-term extension (LTE) phase of ACT-SURE assessed the safety and effectiveness of TCZ as monotherapy and in combination with csDMARDs for up to an additional 108 weeks in patients with RA who had at least a moderate response to TCZ after 24 weeks of treatment.

\section{Methods}

\section{Patient population}

Full inclusion and exclusion criteria for the ACT-SURE core study were published previously $[25,26]$. Briefly, patients were $\geq 18$ years of age with moderately to severely active RA of $\geq 6$ months' duration and an inadequate clinical response (as indicated by Disease Activity Score in 28 joints [DAS28] > 3.2) after a stable dose of csDMARDs and/or TNFis for $\geq 8$ weeks prior to baseline. If patients received oral GCs (prednisone $\leq 10 \mathrm{mg}$ /day or equivalent), they were required to receive stable doses for $\geq 25$ of 28 days before baseline. No washout periods for previous TNFis or csDMARDs were required, and other than requiring a DAS28 $>3.2$, no specific criteria related to disease activity components (e.g., joint counts, erythrocyte sedimentation rate [ESR], or Creactive protein [CRP]) were mandated, allowing enrollment of a broader population. Not all countries in the core study participated in the LTE, as these countries had planned to conclude their participation when TCZ became commercially available to the study patients; the nonparticipating countries (11 of 25) were Austria, Belgium, Denmark, Finland, Germany, India, Ireland, Luxembourg, Sweden, Switzerland, and Turkey. Countries participating in the LTE (14 of 25) were Australia, Canada, Czech Republic, France, Greece, Hungary, Italy, the Netherlands, Poland, Portugal, Romania, Spain, Saudi Arabia, and the United Kingdom.

\section{Study design}

Patients who completed the 24-week ACT-SURE core study who had at least a moderate response based on the European League Against Rheumatism (EULAR) definition criteria were included in the LTE for up to an additional 108 weeks. The end of the LTE was either a follow-up visit at $\geq 4$ weeks after the last dose of TCZ or when TCZ became commercially available, whichever came first. All patients received TCZ intravenously at a dosage of $8 \mathrm{mg} / \mathrm{kg}$ (but not exceeding the maximum dose of $800 \mathrm{mg}$ in a single infusion) every 4 weeks.

At baseline of the 24-week core study, patients initiated TCZ either as monotherapy (for those who were intolerant of their current csDMARD, at the discretion of their rheumatologist) or in combination with their current $\operatorname{csDMARD}(\mathrm{s})$. Any prior biologics were discontinued.

This study was approved by the institutional review board and independent ethics committee of the investigational centers. All patients provided written informed consent in accordance with the Declaration of Helsinki.

\section{Study assessments}

The primary study endpoint was the incidence of AEs and SAEs from baseline of the core study to the last follow-up visit in patients who received TCZ as monotherapy or in combination with csDMARDs. Key secondary safety endpoints included the number and percentage of patients with AEand SAE-related withdrawal and time to AE- and SAErelated discontinuation, discontinuation of TCZ for any 
reason, infusion reaction (an $\mathrm{AE}$ that occurred during or within $24 \mathrm{~h}$ of an infusion), and AEs of special interest, such as serious infections (including opportunistic infections), anaphylaxis, gastrointestinal perforations and related events, major adverse cardiac events (MACE; defined as myocardial infarction, acute coronary syndrome, and stroke), serious/ medically significant hepatic events, spontaneous or serious bleeding, demyelination-related events, and malignant neoplasms (excluding non-melanoma skin cancers that were excised and cured) in the LTE. Patient-years (PY) were calculated as time on study (day of first treatment until the last study day). For events per $100 \mathrm{PY}$, all events were counted. For incidence (i.e., percentage of patients with $\geq 1$ event), the denominator was the number of patients who enrolled in the LTE (intent-to-treat [ITT] population).

Key secondary endpoints assessed effectiveness and included mean change in DAS28 from baseline of the core study, percentage of patients achieving DAS28 remission (< $2.6)$ or low disease activity $(\leq 3.2)$, proportion of patients with a $20 \%, 50 \%$, or $70 \%$ improvement in response, respectively, per the American College of Rheumatology (ACR20/50/70), and mean changes in CRP levels and ESR from baseline. Quality-of-life was assessed using the measures of function (Health Assessment Questionnaire-Disability Index [HAQDI]), disease activity, which incorporated Patient Global Assessment (PtGA) and Physician Global Assessment (PGA), patient global assessment of pain, Medical Outcomes Study 36-item Short Form Health Survey (SF36), and Functional Assessment of Chronic Illness TherapyFatigue (FACIT-fatigue).

\section{Glucocorticoid use}

The GC dose remained stable during the 24-week core study unless tapering was required for safety reasons. During the LTE, the GC dose could be decreased if patients achieved $\geq$ $50 \%$ improvement from baseline of the core study in both swollen joint count based on 66 joints (SJC66) and tender joint count based on 68 joints (TJC68). Dose reductions in GCs were not performed within the 8 weeks before visits at weeks 24, 48, 96, and 108 .

\section{Statistical analysis}

The safety and ITT populations of the core study included all patients who received $\geq 1$ dose of TCZ; the safety and ITT populations of the LTE included all patients who received $\geq 1$ dose at or after week 24 (day 1 of the LTE). All effectiveness analyses were performed on the ITT population. Due to the variable follow-up of patients in this study, data missing due to discontinuation from the long-term extension portion (which was most frequently due to the availability of the commercial drug in the jurisdiction) was not imputed. However, if a patient was missing joint count components of disease activity (but other components were present), missing data were imputed using the last observation carried forward to derive a disease activity score for the visit. All analyses were completed using SAS. Descriptive statistics were used for all endpoints. Patients were classified according to background csDMARD use according to the number of csDMARDs (in addition to TCZ) that were ongoing at baseline as follows: TCZ monotherapy, TCZ + 1 csDMARD and TCZ $+>1$ csDMARD. $t$ tests were used to evaluate the hypothesis of no change from baseline for DAS2 8 in the LTE study population.

\section{Results}

\section{Patient disposition and baseline characteristics}

Of the 1681 patients (from 25 countries) enrolled in the 24-week core study, 440 were from the 11 countries that did not participate in the LTE. Of the remaining 1241 patients from 14 countries, 144 did not complete the core study (56 of these due to $\mathrm{AE}$ ) and 163 did not enter the LTE for logistical, patient preference, or unrelated reasons, including $>50 \%$ due to the commercial availability of TCZ. A total of 934 patients from 169 centers continued on to the LTE phase (Fig. 1). Of the 934 patients who received TCZ (ITT population), 827 (89\%) completed the LTE. Of the 107 patients (11\%) who withdrew from the LTE, $68(7 \%)$ withdrew for reasons not due to safety and 39 (4\%) withdrew due to safety reasons.

A total of 593 patients (63\%) were TNFi naïve, $140(15 \%)$ were previous TNFi users (TNFi discontinued $>2$ months before baseline), and 201 (22\%) were recent TNFi users (TNFi therapy discontinued $\leq 2$ months before baseline). From baseline of the core study to the end of the LTE, the 934 patients included in the LTE had a median (range) duration of exposure to TCZ of 64.3 (27.1-151.7) weeks; exposure to study medication was 1228.1 PY. The total on-study duration was 1265.62 PY. In the LTE phase, the 934 patients had a median (range) duration of exposure to TCZ of 38.9 (4.1-123.3) weeks; exposure to study medication in the LTE was 813.3 PY. A total of 117 patients (13\%) received TCZ as monotherapy, $612(66 \%)$ received TCZ +1 csDMARD, and $205(22 \%)$ received TCZ $+>1$ csDMARD. Overall, the most common csDMARDs were MTX (666 patients [71\%]), hydroxychloroquine (147 patients [16\%]), sulfasalazine (129 patients [14\%]), and leflunomide (99 patients [11\%]) (Online Resource 1).

Demographic data are summarized in Table 1 . The majority of patients were female $(81 \%)$, and the median (range) age was 55 (19-84) years. The median (range) duration of RA was $9.0(0.5-44.3), 7.2(0.4-48.7)$, and $5.7(0.5-48.2)$ years in the TCZ monotherapy, TCZ + 1 csDMARD, and TCZ + > 1 


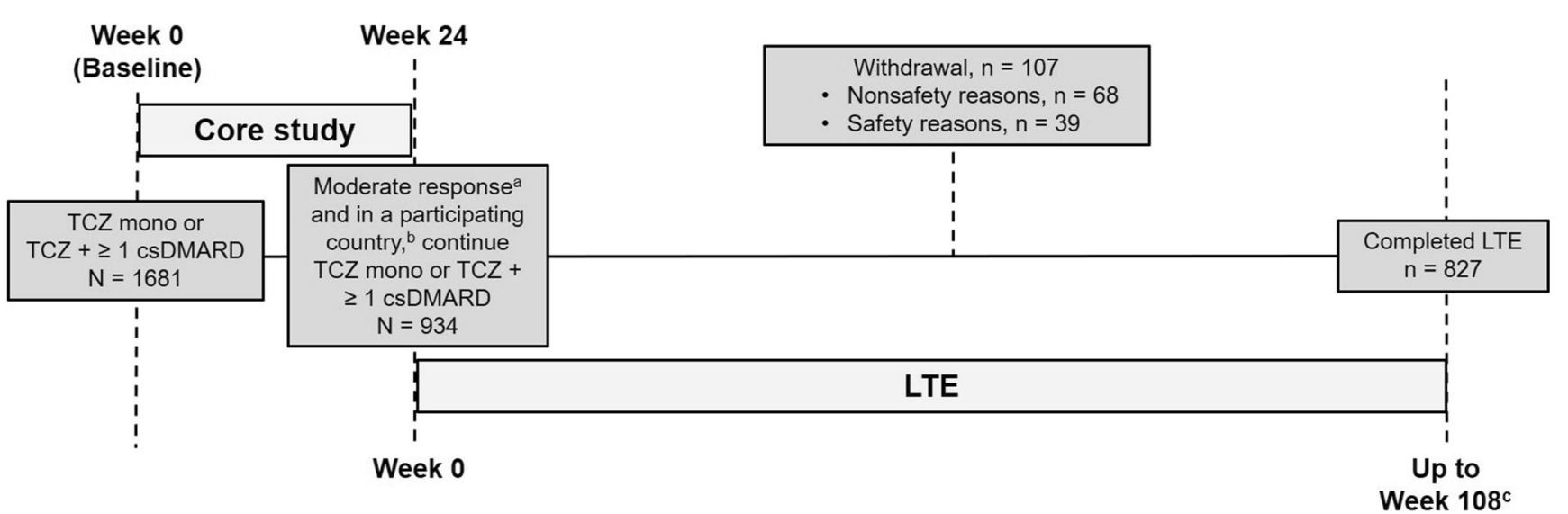

Fig. 1 Study design and patient disposition. $\operatorname{cs} D M A R D$, conventional synthetic disease-modifying antirheumatic drug; EULAR, European League Against Rheumatism; LTE, long-term extension; mono, monotherapy; $T C Z$, tocilizumab. ${ }^{a}$ Based on EULAR criteria. ${ }^{\mathrm{b}}$ Participating countries included Australia, Canada, Czech Republic,

csDMARD groups, respectively. In the TCZ monotherapy group, 10 patients (9\%) were csDMARD/TNFi naïve before the first dose of TCZ in the core study, whereas in the TCZ + 1 csDMARD and TCZ +> 1 csDMARD groups, 270 patients (44\%) and 135 patients (66\%) were csDMARD/TNFi naïve, respectively. With regard to previous TNFi use, 39 (33\%), 393 (64\%), and 161 (78\%) patients were TNFi naïve in the TCZ monotherapy, $\mathrm{TCZ}+1$ csDMARD and $\mathrm{TCZ}+>1$ csDMARD groups, respectively.

In the 934 patients who went on to enter the LTE, the median SJC was 12.0 and 4.0 and the median TJC was 21.0 and 6.0 at baseline and week 24 of the core study, respectively. The median CRP levels and ESR at baseline were $0.84 \mathrm{mg} / \mathrm{dL}$ and $32.0 \mathrm{~mm} / \mathrm{h}$, respectively, and $0.13 \mathrm{mg} /$ $\mathrm{dL}$ and $6.0 \mathrm{~mm} / \mathrm{h}$ at week 24 , respectively. At baseline and week 24, the median PtGA was 63.0 and 27.0, median PGA was 60.0 and 20.0, patient median global assessment of pain was 58.0 and 26.0, and median HAQ-DI was 1.50 and 1.00 , respectively.

\section{Safety}

From baseline of the core study to the end of the LTE, 842 patients (90\%) experienced a total of 5145 AEs; 675 (72\%) experienced an $\mathrm{AE}$ considered by the investigator to be related to TCZ (Table 2). The overall event rate (95\% CI) of AEs per $100 \mathrm{PY}$ was 406.5 (395.5, 417.8), with rates of 475.6 (439.8, $513.5)$ in the TCZ monotherapy, $366.2(353.3,379.5)$ in the $\mathrm{TCZ}+1$ csDMARD, and $487.8(462.9,513.6)$ in the $\mathrm{TCZ}+>1$ csDMARD groups. During the LTE, 36 patients (4\%) had AEs leading to withdrawal, and the median time to an AE-related withdrawal due to TCZ treatment was 374.5 days. AEs leading to dose modification occurred in 172 patients $(18 \%)$ during the LTE. Infusion reactions occurred in 113 patients (7\%) during the core study and 27
France, Greece, Hungary, Italy, the Netherlands, Poland, Portugal, Romania, Spain, Saudi Arabia, and the United Kingdom. ${ }^{\circ}$ The end of the LTE was either a follow-up visit at $\geq 4$ weeks after the last dose of TCZ (up to 104 weeks) or when TCZ became commercially available in participating countries, whichever came first

(3\%) during the LTE. Most infusion reactions were not serious and did not result in dose interruption or discontinuation.

From baseline of the core study to the end of the LTE, 87 patients $(9 \%)$ experienced a total of 112 SAEs. Of those experiencing $\geq 1 \mathrm{SAE}, 9 \%, 9 \%$, and $10 \%$ were in the TCZ monotherapy, TCZ + 1 csDMARD, and $\mathrm{TCZ}+>1$ csDMARD groups, respectively. The overall event rate (95\% CI) of SAEs per $100 \mathrm{PY}$ was $8.8(7.3,10.6)$, with rates of $9.5(5.0,16.2)$ in the TCZ monotherapy, $8.9(7.0,11.2)$ in the TCZ + 1 csDMARD, and $8.4(5.5,12.5)$ in the TCZ + 1 csDMARD groups.

The overall event rate $(95 \% \mathrm{CI})$ of infections per $100 \mathrm{PY}$ from baseline of the core study to the end of the LTE was 99.2 (93.8, 104.9), and the overall event rate $(95 \% \mathrm{CI})$ of serious infections per $100 \mathrm{PY}$ was $2.2(1.5,3.2)$. A total of 541 patients (60\%) experienced infection and $26(3 \%)$ had a serious infection. During the LTE period, the overall event rate (95\% CI) of infections per 100 PY was $87.2(80.9,93.8)$ and that of serious infections per $100 \mathrm{PY}$ was $2.8(1.8,4.2)$ (Online Resource 2). The event rate of serious infections did not increase with increasing exposure to treatment. During the LTE, 377 patients $(40 \%)$ experienced infection and $22(2 \%)$ experienced a serious infection.

In the LTE, 3 patients $(0.3 \%)$ experienced a MACE (myocardial infarction in all 3 patients) and $8(0.9 \%)$ experienced a stroke. A total of 4 patients $(0.2 \%)$ died during the core study and $3(0.3 \%)$ died during the LTE (Online Resource 2). All patient deaths during the LTE occurred after study treatment had stopped (Online Resource 3).

\section{Laboratory parameters}

The overall hematology and clinical chemistry profiles showed that the majority of laboratory values remained within the clinically acceptable range throughout the 108-week 
Table 1 Baseline demographics (at week 0 of the core study) in patients included in the LTE

\begin{tabular}{|c|c|c|c|c|}
\hline & $\begin{array}{l}\text { TCZ mono } \\
n=117\end{array}$ & $\begin{array}{l}\text { TCZ }+1 \text { csDMARD } \\
n=612\end{array}$ & $\begin{array}{l}\text { TCZ }+>1 \text { csDMARD } \\
n=205\end{array}$ & $\begin{array}{l}\text { Total patients } \\
N=934\end{array}$ \\
\hline Female, $\%(n)$ & $80.3(94)$ & $82.4(504)$ & $75.6(155)$ & $80.6(753)$ \\
\hline Age, median (range), years & $\begin{array}{l}56.0 \\
(19-80)\end{array}$ & $\begin{array}{l}55.0 \\
(20-84)\end{array}$ & $\begin{array}{l}55.0 \\
(19-78)\end{array}$ & $\begin{array}{l}55.0 \\
(19-84)\end{array}$ \\
\hline Duration of RA, median (range), years & $\begin{array}{l}9.0 \\
(0.5-44.3)\end{array}$ & $\begin{array}{l}7.2 \\
(0.4-48.7)\end{array}$ & $\begin{array}{l}5.7 \\
(0.5-48.2)\end{array}$ & $\begin{array}{c}7.0 \\
(0.4-48.7)\end{array}$ \\
\hline Weight, median (range), $\mathrm{kg}$ & $\begin{array}{l}70.2 \\
(45.0-115.5)\end{array}$ & $\begin{array}{l}70.0 \\
(43.0-143.0)\end{array}$ & $\begin{array}{l}75.0 \\
(38.0-137.5)\end{array}$ & $\begin{array}{l}71.0 \\
(38.0-143.0)\end{array}$ \\
\hline \multicolumn{5}{|l|}{ No. of previous csDMARDs/TNFis, $\%(n)$} \\
\hline 0 & $8.5(10)$ & $44.1(270)$ & $65.9(135)$ & $44.4(415)$ \\
\hline 1 & $26.5(31)$ & $30.6(187)$ & $16.1(33)$ & $26.9(251)$ \\
\hline 2 & $19.7(23)$ & $11.9(73)$ & $10.7(22)$ & $12.6(118)$ \\
\hline 3 & $10.3(12)$ & $6.0(37)$ & $2.0(4)$ & $5.7(53)$ \\
\hline 4 & $17.9(21)$ & $3.3(20)$ & $3.9(8)$ & $5.2(49)$ \\
\hline$>4$ & $17.1(20)$ & $4.1(25)$ & $1.5(3)$ & $5.1(48)$ \\
\hline \multicolumn{5}{|l|}{ No. of previous TNFis, $\%(n)$} \\
\hline 0 & $33.3(39)$ & $64.2(393)$ & $78.5(161)$ & $63.5(593)$ \\
\hline 1 & $41.9(49)$ & $25.8(158)$ & $12.7(26)$ & $24.9(233)$ \\
\hline 2 & $19.7(23)$ & $9.0(55)$ & $7.8(16)$ & $10.1(94)$ \\
\hline 3 & $5.1(6)$ & $1.0(6)$ & $1.0(2)$ & $1.5(14)$ \\
\hline \multicolumn{5}{|l|}{ No. of background csDMARDs, $\%(n)$} \\
\hline 0 & $100.0(117)$ & 0 & 0 & $12.5(117)$ \\
\hline 1 & 0 & $100.0(612)$ & 0 & $65.5(612)$ \\
\hline 2 & 0 & 0 & $81.0(166)$ & $17.8(166)$ \\
\hline$\geq 3$ & 0 & 0 & $19.0(39)$ & $4.2(39)$ \\
\hline Glucocorticoid use, \% (n) & $53.0(62)$ & $54.6(334)$ & $34.1(70)$ & $49.9(466)$ \\
\hline Baseline glucocorticoid dose, mean (SD), mg/day & $7.1(3.0)$ & $6.8(3.6)$ & $7.4(5.6)$ & $7.0(3.9)$ \\
\hline DAS28, median (range) & $\begin{array}{l}6.1 \\
(3.4-8.7)\end{array}$ & $\begin{array}{l}6.0 \\
(2.4-9.1)\end{array}$ & $\begin{array}{l}6.0 \\
(2.2-8.7)\end{array}$ & $\begin{array}{c}6.0 \\
(2.1-9.1)\end{array}$ \\
\hline SJC66, median (range) & $\begin{array}{l}12.0 \\
(1.0-50.0)\end{array}$ & $\begin{array}{l}11.5 \\
(0.0-60.0)\end{array}$ & $\begin{array}{l}12.0 \\
(0.0-52.0)\end{array}$ & $\begin{array}{l}12.0 \\
(0.0-60.0)\end{array}$ \\
\hline TJC68, median (range) & $\begin{array}{l}24.0 \\
(0.0-68.0)\end{array}$ & $\begin{array}{l}20.0 \\
(0.0-68.0)\end{array}$ & $\begin{array}{l}23.0 \\
(0.0-68.0)\end{array}$ & $\begin{array}{l}21.0 \\
(0.0-68.0)\end{array}$ \\
\hline PGA, median (range), 100-mm VAS & $\begin{array}{l}63.0 \\
(14.0-100.0)\end{array}$ & $\begin{array}{l}60.0 \\
(12.0-100.0)\end{array}$ & $\begin{array}{l}58.0 \\
(10.0-100.0)\end{array}$ & $\begin{array}{l}60.0 \\
(10.0-100.0)\end{array}$ \\
\hline PtGA, median (range), 100-mm VAS & $\begin{array}{l}65.0 \\
(10.0-97.0)\end{array}$ & $\begin{array}{l}63.0 \\
(2.0-100.0)\end{array}$ & $\begin{array}{l}60.5 \\
(3.0-100.0)\end{array}$ & $\begin{array}{l}63.0 \\
(2.0-100.0)\end{array}$ \\
\hline Pain, median (range), 100-mm VAS & $\begin{array}{l}61.0 \\
(0.0-100.0)\end{array}$ & $\begin{array}{l}58.0 \\
(1.0-100.0)\end{array}$ & $\begin{array}{l}55.0 \\
(0.0-100.0)\end{array}$ & $\begin{array}{l}58.0 \\
(0.0-100.0)\end{array}$ \\
\hline HAQ-DI, median (range) & $1.6(0.0-2.9)$ & $1.5(0.0-3.0)$ & $1.5(0.0-3.0)$ & $1.5(0.0-3.0)$ \\
\hline SF-36, physical component, median (range) & $\begin{array}{l}28.8 \\
(11.1-52.7)\end{array}$ & $\begin{array}{l}29.5 \\
(7.1-57.7)\end{array}$ & $\begin{array}{l}29.0 \\
(12.1-57.3)\end{array}$ & $\begin{array}{l}29.3 \\
(7.1-57.7)\end{array}$ \\
\hline SF-36, mental component, median (range) & $\begin{array}{l}38.0 \\
(14.0-72.8)\end{array}$ & $\begin{array}{l}36.2 \\
(7.2-76.5)\end{array}$ & $\begin{array}{l}36.8 \\
(11.8-73.8)\end{array}$ & $\begin{array}{l}36.7 \\
(7.2-76.5)\end{array}$ \\
\hline ESR, median (range), $\mathrm{mm} / \mathrm{h}$ & $\begin{array}{l}36.0 \\
(2.0-126.0)\end{array}$ & $\begin{array}{l}33.0 \\
(1.0-150.0)\end{array}$ & $\begin{array}{l}27.0 \\
(1.0-107.0)\end{array}$ & $\begin{array}{l}32.0 \\
(1.0-150.0)\end{array}$ \\
\hline CRP, median (range), mg/dL & $\begin{array}{l}1.8 \\
(0.0-13.9)\end{array}$ & $\begin{array}{l}0.8 \\
(0.0-28.2)\end{array}$ & $\begin{array}{l}0.6 \\
(0.0-16.8)\end{array}$ & $\begin{array}{c}0.8 \\
(0.0-28.2)\end{array}$ \\
\hline
\end{tabular}

$C R P$ C-reactive protein, $c S D M A R D$ conventional synthetic disease-modifying antirheumatic drug, DAS28 Disease Activity Score based on 28 joints, ESR erythrocyte sedimentation rate, HAQ-DI Health Assessment Questionnaire-Disability Index, LTE long-term extension, mono monotherapy, $P G A$ Physician Global Assessment, PtGA Patient Global Assessment, $R A$ rheumatoid arthritis, $S D$ standard deviation, $S F$-36 Medical Outcomes Study 36item Short Form Health Survey, SJC66 swollen joint count based on 66 joints, TCZ tocilizumab, TJC68 tender joint count based on 68 joints, TNFi tumor necrosis factor inhibitor, $V A S$ visual analog scale

period of the LTE, with levels of aspartate aminotransferase (AST) and liver function parameters increasing slightly and levels of alkaline phosphatase decreasing slightly over time. Of the patients who continued on to the LTE phase of the study, 94\% had a normal alanine aminotransferase (ALT) value recorded at the core study baseline.
Less than $0.3 \%$ of patients had 2 or more consecutive values that were $3 \times$ the upper limit of normal (ULN), and no patients had a sustained elevation of ALT. A total of 18 patients $(2 \%)$ had an ALT elevation $>3 \times$ higher than the ULN. None of these patients were in the TCZ monotherapy group, 17 were in the TCZ + 1 csDMARD group (most patients were 
Table 2 Principal safety outcomes reported during the core study and LTE

\begin{tabular}{|c|c|c|c|c|}
\hline & $\begin{array}{l}\text { TCZ mono } \\
n=117 \\
(133.5 \mathrm{PY})\end{array}$ & $\begin{array}{l}\text { TCZ }+1 \text { csDMARD } \\
n=612 \\
(806.9 \mathrm{PY})\end{array}$ & $\begin{array}{l}\text { TCZ }+>1 \text { csDMARD } \\
n=205 \\
(287.7 \mathrm{PY})\end{array}$ & $\begin{array}{l}\text { Total patients } \\
N=934 \\
(1228.1 \mathrm{PY})\end{array}$ \\
\hline Patients with $\geq 1 \mathrm{AE}, \%(n)[95 \% \mathrm{CI}]$ & $\begin{array}{l}90.6(106) \\
{[83.8,95.2]}\end{array}$ & $\begin{array}{l}89.4(547) \\
{[86.7,91.7]}\end{array}$ & $\begin{array}{l}92.2(189) \\
{[87.6,95.5]}\end{array}$ & $\begin{array}{l}90.1(842) \\
{[88.1,92.0]}\end{array}$ \\
\hline TCZ-related $\mathrm{AE}^{\mathrm{a}}$ & $\begin{array}{l}69.2(81) \\
{[60.0,77.4]}\end{array}$ & $\begin{array}{l}70.8(433) \\
{[67.0,74.3]}\end{array}$ & $\begin{array}{l}78.5(161) \\
{[72.3,84.0]}\end{array}$ & $\begin{array}{l}72.3(675) \\
{[69.3,75.1]}\end{array}$ \\
\hline AE, total no. of events & 653 & 3048 & 1444 & 5145 \\
\hline AE rate $(95 \% \mathrm{CI})$, events/100 PY & $\begin{array}{l}475.6 \\
(439.8,513.5)\end{array}$ & $\begin{array}{l}366.2 \\
(353.3,379.5)\end{array}$ & $\begin{array}{l}487.8 \\
(462.9,513.6)\end{array}$ & $\begin{array}{l}406.5 \\
(395.5,417.8)\end{array}$ \\
\hline Patients with $\geq 1 \mathrm{SAE}, \%(n)[95 \% \mathrm{CI}]$ & $\begin{array}{l}9.4(11) \\
{[4.8,16.2]}\end{array}$ & $\begin{array}{l}9.2(56) \\
{[7.0,11.7]}\end{array}$ & $\begin{array}{l}9.8(20) \\
{[6.1,14.7]}\end{array}$ & $\begin{array}{l}9.3(87) \\
{[7.5,11.4]}\end{array}$ \\
\hline TCZ-related SAE ${ }^{\mathrm{a}}$ & $\begin{array}{l}4.3(5) \\
{[1.4,9.7]}\end{array}$ & $\begin{array}{l}3.3(20) \\
{[2.0,5.0]}\end{array}$ & $\begin{array}{l}2.9(6) \\
{[1.1,6.3]}\end{array}$ & $\begin{array}{l}3.3(31) \\
{[2.3,4.7]}\end{array}$ \\
\hline SAE, total no. of events & 13 & 74 & 25 & 112 \\
\hline SAE rate $(95 \% \mathrm{CI})$, events/100 PY & $\begin{array}{l}9.5 \\
(5.0,16.2)\end{array}$ & $\begin{array}{l}8.9 \\
(7.0,11.2)\end{array}$ & $\begin{array}{l}8.4 \\
(5.5,12.5)\end{array}$ & $\begin{array}{l}8.8 \\
(7.3,10.6)\end{array}$ \\
\hline AE leading to withdrawal, $\%(n)[95 \% \mathrm{CI}]$ & $\begin{array}{l}3.4(4) \\
{[0.9,8.5]}\end{array}$ & $\begin{array}{l}4.1(25) \\
{[2.7,6.0]}\end{array}$ & $\begin{array}{l}3.4(7) \\
{[1.4,6.9]}\end{array}$ & $\begin{array}{l}3.9(36) \\
{[2.7,5.3]}\end{array}$ \\
\hline AE leading to dose modification, $\%(n)[95 \% \mathrm{CI}]$ & $\begin{array}{l}23.1(27) \\
{[15.8,31.8]}\end{array}$ & $\begin{array}{l}25.3(155) \\
{[21.9,29.0]}\end{array}$ & $\begin{array}{l}30.2(62) \\
{[24.0,37.0]}\end{array}$ & $\begin{array}{l}26.1(244) \\
{[23.3,29.1]}\end{array}$ \\
\hline Infection rate $(95 \% \mathrm{CI})$, events/100 PY & $\begin{array}{l}130.4 \\
(112.0,150.9)\end{array}$ & $\begin{array}{l}91.9 \\
(85.5,98.7)\end{array}$ & $\begin{array}{l}105.4 \\
(94.0,117.8)\end{array}$ & $\begin{array}{l}99.2 \\
(93.8,104.9)\end{array}$ \\
\hline Infection, $\%(n)^{\mathrm{b}}$ & $64.1(75)$ & $55.9(342)$ & $60.5(124)$ & $57.9(541)$ \\
\hline Bronchitis & $5.1(6)$ & $6.5(40)$ & $3.4(7)$ & $5.7(53)$ \\
\hline Lower respiratory tract infection $^{\mathrm{c}}$ & $11.1(13)$ & $3.9(24)$ & $6.8(14)$ & $5.5(51)$ \\
\hline Nasopharyngitis & $13.7(16)$ & $14.5(89)$ & $13.7(28)$ & $14.2(133)$ \\
\hline Sinusitis & $5.1(6)$ & $3.3(20)$ & $5.4(11)$ & $4.0(37)$ \\
\hline Upper respiratory tract infection & $6.8(8)$ & $9.2(56)$ & $10.2(21)$ & $9.1(85)$ \\
\hline Urinary tract infection & $7.7(9)$ & $4.6(28)$ & $3.9(8)$ & $4.8(45)$ \\
\hline Serious infection, $\%(n)$ & $2.6(3)$ & $3.1(19)$ & $2.0(4)$ & $2.8(26)$ \\
\hline Serious infection rate $(95 \% \mathrm{CI})$, events/100 PY & $\begin{array}{l}2.2 \\
(0.5,6.4)\end{array}$ & $\begin{array}{l}2.3 \\
(1.4,3.6)\end{array}$ & $\begin{array}{l}2.0 \\
(0.7,4.4)\end{array}$ & $\begin{array}{l}2.2 \\
(1.5,3.2)\end{array}$ \\
\hline Infusion reaction, $\%(n)[95 \% \mathrm{CI}]$ & $\begin{array}{l}14.5(17) \\
{[8.7,22.2]}\end{array}$ & $\begin{array}{l}8.7(53) \\
{[6.6,11.2]}\end{array}$ & $\begin{array}{l}16.6(34) \\
{[11.8,22.4]}\end{array}$ & $\begin{array}{l}11.1(104) \\
{[9.2,13.3]}\end{array}$ \\
\hline MI/acute coronary syndrome, $\%(n)[95 \% \mathrm{CI}]$ & $0.0(0)$ & $0.0(0)$ & $\begin{array}{l}1.5(3) \\
{[0.3,4.2]}\end{array}$ & $\begin{array}{l}0.3(3) \\
{[0.1,0.9]}\end{array}$ \\
\hline Stroke, \% (n) $[95 \% \mathrm{CI}]$ & $\begin{array}{l}2.6(3) \\
{[0.5,7.3]}\end{array}$ & $\begin{array}{l}1.0(6) \\
{[0.4,2.1]}\end{array}$ & $\begin{array}{l}0.5(1) \\
{[0.0,2.7]}\end{array}$ & $\begin{array}{l}1.1(10) \\
{[0.5,2.0]}\end{array}$ \\
\hline Death, \% (n) $[95 \% \mathrm{CI}]$ & $0.0(0)$ & $\begin{array}{l}0.2(1) \\
{[0.0,0.9]}\end{array}$ & $\begin{array}{l}1.0(2) \\
{[0.1,3.5]}\end{array}$ & $\begin{array}{l}0.3(3) \\
{[0.1,0.9]}\end{array}$ \\
\hline Neoplasm (benign, malignant and unspecified), \% ( $n$ ) & $1.7(2)$ & $3.1(19)$ & $2.9(6)$ & $2.9(27)$ \\
\hline
\end{tabular}

$A E$ adverse event, $c S D M A R D$ conventional synthetic disease-modifying antirheumatic drug, LTE long-term extension, $M I$ myocardial infarction, mono monotherapy, $P Y$ patient-year, $S A E$ serious adverse event, $T C Z$ tocilizumab

${ }^{\text {a }}$ Considered remotely, possibly, or probably related to TCZ as determined by the investigator

${ }^{\mathrm{b}}$ Individual infections listed are those that occurred in $\geq 4 \%$ of total patients

${ }^{\mathrm{c}}$ Included viral lower respiratory tract infections

receiving MTX only, and 2 were receiving leflunomide), and 1 was in the TCZ $+>1$ csDMARD group (receiving MTX and sulfasalazine). Four patients $(0.4 \%)$ had an AST elevation $>3 \times$ higher than the ULN at a single time point during the LTE (all receiving MTX only).

\section{Effectiveness}

Overall, a statistically significant improvement in mean DAS28 was observed after 4 weeks of treatment in the core study (mean [SD] DAS28 change, $-1.91[1.153] ; P<0.0001$ ) 
[25], and this improvement increased progressively during the core study and was maintained during the LTE (Fig. 2). In the total patient population, the mean (SD) DAS28 change was -4.12 (1.18), $P<0.0001$, from baseline up to week 108 . The percentage of patients in clinical remission (DAS28 <2.6) was consistent in the LTE independent of the TCZ treatment regimen (Fig. 3). Similar results were observed for Clinical Disease Activity Index (CDAI) and Simplified Disease Activity Index (SDAI) as shown in Online Resources 4 and 5.

Remission was observed in 541 of 930 patients $(58 \%)$ at week 24 of the core study (LTE week 0), 479 of 759 (63\%) at LTE week 24, 276 of 440 (63\%) at week 48, 151 of $216(70 \%)$ at week 72, and 30 of $42(71 \%)$ at week 108 . The overall ACR response rates increased steadily over the 24-week core study and were maintained during the LTE (Fig. 4), with 95\%, 83\%, and $60 \%$ of patients (cumulative) achieving ACR20/50/70 response, respectively. CRP levels and ESR decreased during the 24-week core study; on day 1 of the LTE, among the total patients, mean values for CRP and ESR were $<0.5 \mathrm{mg} / \mathrm{dL}$ and $<9.5 \mathrm{~mm} / \mathrm{h}$, respectively.

The mean HAQ-DI scores improved over time during the core study and improvements were maintained during the LTE (Online Resource 6 1A). By week 24 of the core study, 33\% of patients achieved HAQ-DI remission $(<0.5)$ and $74 \%$ showed a clinically meaningful improvement from baseline (change in HAQ-DI $\geq 0.22$ ); these results were maintained during the LTE (data not shown).

The patient-reported outcome (PRO) scores-including the mean PtGA, PGA, pain, FACIT-fatigue, and SF-36 physical and mental component scores-improved from baseline of the core study and were maintained in the LTE (Online Resource 6 1B-1D). Results for all PRO measurements were comparable between patients in the TCZ monotherapy, $\mathrm{TCZ}+1$ csDMARD and TCZ + > 1 csDMARD groups.

\section{Glucocorticoid use}

Among patients in the LTE, $466(50 \%)$ received GCs before the start of the core study and continued them for $\geq 1$ day after the first TCZ dose, including 62 of the 117 patients (53\%) in the TCZ monotherapy group, 334 of $612(55 \%)$ in the $\mathrm{TCZ}+1$ csDMARD group and 70 of $205(34 \%)$ in the $\mathrm{TCZ}+>1$ csDMARD group. Among the 466 patients receiving GCs, $261(56 \%)$ received $\leq 5 \mathrm{mg} /$ day and 205 (44\%) received $>5 \mathrm{mg}$ /day at baseline of the core study. At the end of their participation in the LTE, 306 patients $(66 \%)$ were receiving $\leq 5 \mathrm{mg} /$ day and $160(34 \%)$ were receiving $>5 \mathrm{mg}$ /day (Online Resource 7). A total of 66 patients (TCZ monotherapy, $n=13 ; \mathrm{TCZ}+1$ csDMARD, $n=37 ; \mathrm{TCZ}+>1$ csDMARD, $n=16$ ) had discontinued steroids completely by the end of their participation in the LTE. Although GC tapering was permitted per the study protocol, no consistent pattern of tapering was observed.

\section{Discussion}

This LTE of the phase IIIb, multinational, open-label ACTSURE study demonstrated that the safety, tolerability, and effectiveness of TCZ administered intravenously in patients with moderate to severe RA were maintained with long-term exposure (median exposure of 64.3 weeks) in patients who had responded to TCZ after the 24-week core study. Previous clinical trials have shown the long-term efficacy and safety of TCZ [18, 21-24, 27]; however, the patient population of the ACT-SURE LTE study was more representative of the broader range of patients with RA seen in clinical practice, given the minimal restrictions on concomitant medications and previous csDMARD and TNFi use and the lack of specific minimum criteria related to specific disease activity components in contrast to what is usually required in most phase III trials in RA. Thus, the ACT-SURE LTE adds to the growing body of evidence supporting the long-term effectiveness and safety of TCZ in a patient population similar to that seen in rheumatology practices.

The safety profile of TCZ in the present LTE was consistent with that observed in previous TCZ studies [18, 22, 23, 27], and no new safety signals were observed. The rates of AEs per 100 PY decreased over time (593.0 in the 24-week core study vs 406.5 over the duration of the entire study [core plus LTE]). As expected, the rates of AEs per 100 PY during the LTE period were lower than those during the core study (307.8). The rates of SAEs per $100 \mathrm{PY}$ also decreased over time (20.1 in the core study vs 8.5 over the duration of the entire study). Furthermore, as observed in other studies [21, 28], rates of infection were highest in the first 6 months of exposure. Overall, MACE and malignancies were low, with sporadic events occurring during the LTE. In addition, AEs leading to withdrawal and infusion reactions did not increase over the length of the study.

The rates of SAEs and infections per $100 \mathrm{PY}$ were higher in the TCZ monotherapy group than in the TCZ +1 csDMARD and $\mathrm{TCZ}+>1 \mathrm{csDMARD}$ groups. This could in part be due to the differences in clinical characteristics between the groups. The TCZ monotherapy group had a higher proportion of csDMARD/TNFi-experienced patients. In previous TCZ studies, rates of SAEs were slightly higher in patients who were inadequate responders to TNFis than those who were TNFi naïve $[10,11,13]$. In addition, the duration of disease was longer in the TCZ monotherapy group than in the TCZ +1 csDMARD and TCZ $+>1$ csDMARD groups. Furthermore, patients in the TCZ monotherapy group may also have had potentially more disease burden at baseline, with numerically worse mean HAQ-DI and TJC68 responses, than those in the $\mathrm{TCZ}+\geq 1$ csDMARD groups.

Effectiveness results were consistent with those in previous studies of TCZ [10, 13, 16, 29, 30]. For the mean change in DAS28 response from baseline of the core study to LTE week 
Fig. 2 Improvement in mean DAS28 response from week 0 of the core study to week 108 of the LTE. csDMARD, conventional synthetic disease-modifying antirheumatic drug; $D A S 28$, Disease Activity Score based on 28 joints; mono, monotherapy; $T C Z$, tocilizumab

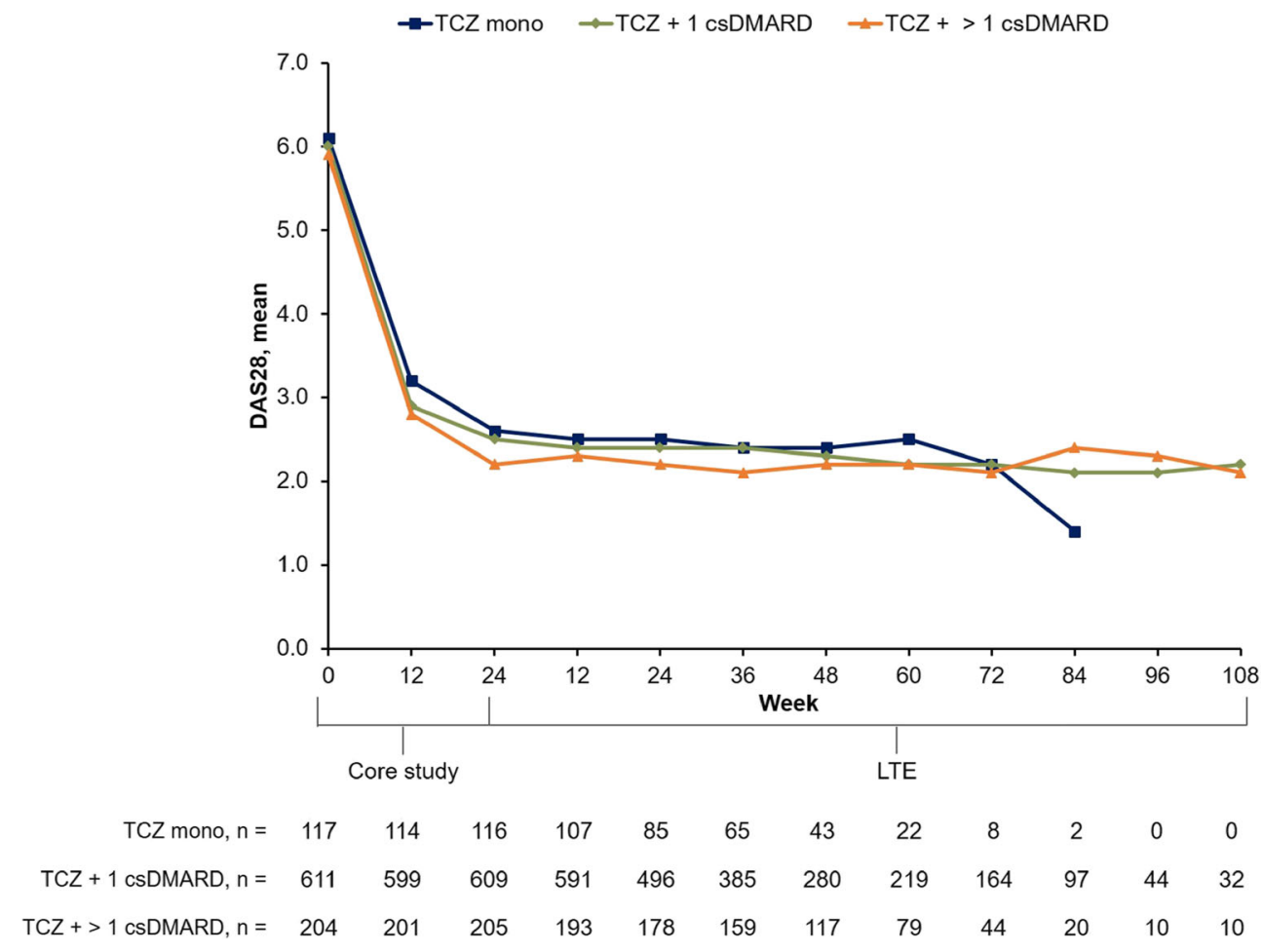

108 , the proportion of patients achieving clinical remission (DAS28 <2.6) and the overall ACR response rates were similar across the TCZ monotherapy, TCZ +1 csDMARD, and $\mathrm{TCZ}+>1$ csDMARD groups. Consistent with previous studies, effectiveness was similar between patients receiving TCZ monotherapy and those receiving TCZ in combination with csDMARDs [16, 18, 20, 26] and was maintained over 132 weeks. Improvements in PRO scores were also similar to those in previous studies of TCZ and remained stable over time [10-12, 31-33].

In the present study, a greater percentage of patients in the TCZ monotherapy group had received prior csDMARDs or TNFis than patients in the TCZ +1 csDMARD and TCZ $+>1$ csDMARD groups. Furthermore, patients receiving TCZ monotherapy had a longer disease duration than patients who received $\mathrm{TCZ}+\geq 1$ csDMARD. Patients in the TCZ
Fig. 3 DAS28 remission and LDA in the 108-week LTE. csDMARD, conventional synthetic disease-modifying antirheumatic drug; DAS28, Disease Activity Score based on 28 joints; $L D A$, low disease activity; $L T E$, long-term extension; mono, monotherapy; $T C Z$, tocilizumab. ${ }^{\mathrm{a}}$ Percentage of patients in DAS28 remission and with LDA among patients observed at each time point

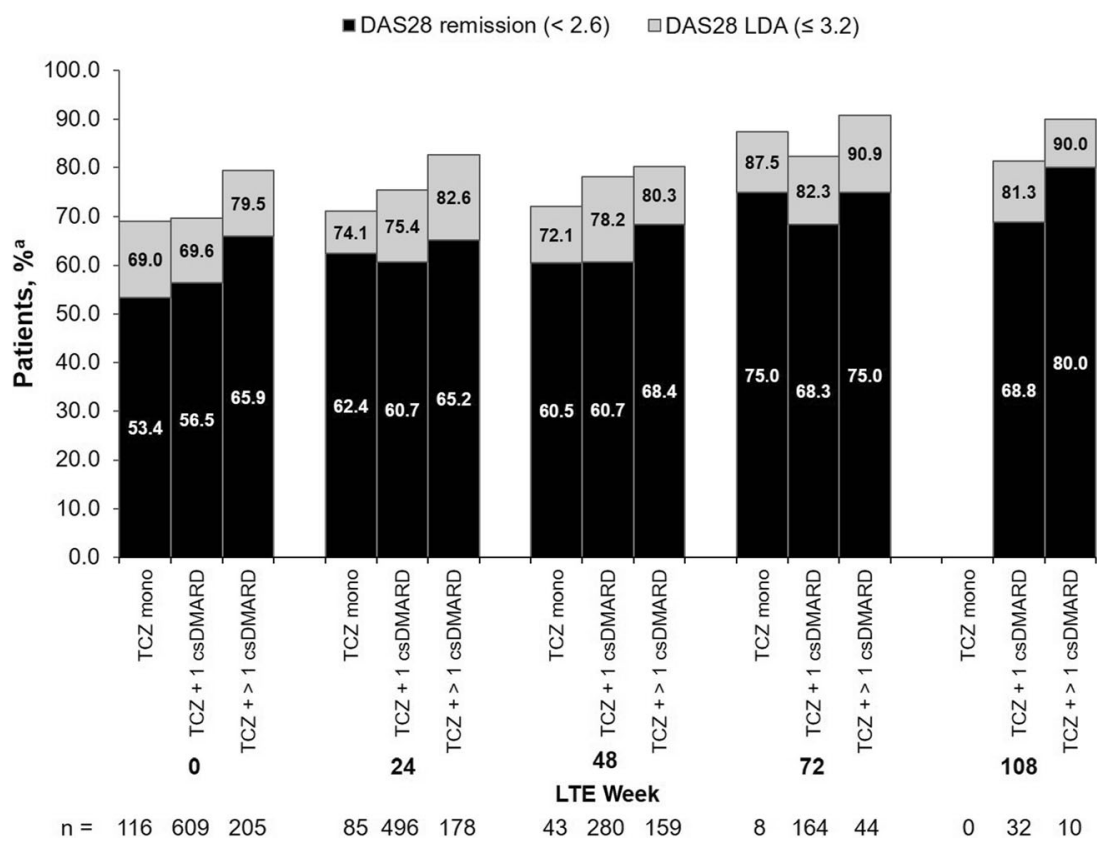


Fig. 4 Cumulative percentage of patients with first ACR20/50/70 response in the 108-week LTE. Solid lines represent ACR20 response, dotted lines represent ACR50 response, and dashed lines represent ACR70 response. ACR $20 / 50 / 70,20 \%, 50 \%$, or $70 \%$ improvement in response, respectively, per the American College of Rheumatology; csDMARD, conventional synthetic disease-modifying antirheumatic drug; LTE, longterm extension; mono, monotherapy; $T C Z$, tocilizumab

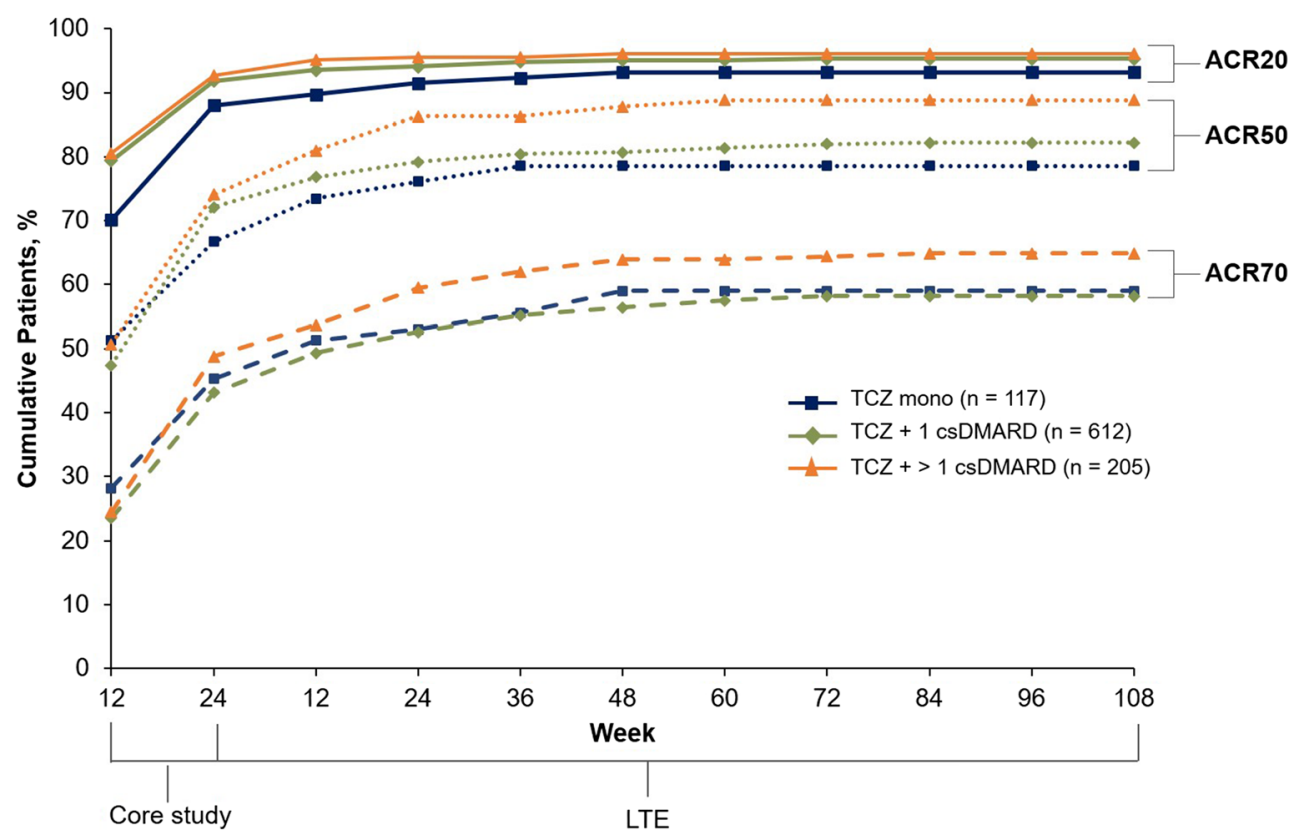

monotherapy and TCZ + 1 csDMARD groups had similar rates of GC use as well as GC doses. These results are similar to those from the multinational, open-label, single-arm TOZURA study [34]. In the present study, the longer disease duration in the TCZ monotherapy group may contribute to monotherapy use because patients with longer disease duration may attempt to taper csDMARDs or develop comorbidities that prevent the use of concomitant csDMARDs.

Overall, fewer patients received GC doses $>5 \mathrm{mg}$ /day at the end of their LTE study participation than at baseline of the core study. Furthermore, the proportion of patients receiving GCs at doses $>7.5 \mathrm{mg}$ /day decreased from $30 \%$ at baseline to $20 \%$ at the end of the patients' participation in the study. According to the current EULAR recommendations, longterm use of GCs, especially at doses $>5 \mathrm{mg} /$ day, should be avoided because of the many potential risks associated with doses of $>10 \mathrm{mg} /$ day $[2,35]$. Increased overall and cardiovascular mortality has been reported in patients with RA receiving a $\mathrm{GC}$ dose $>7.5 \mathrm{mg} /$ day [36]. In addition, results of observational studies have shown a dose-dependent increase in the risk of serious infections in patients with RA who receive GCs [37].

A limitation of this study is the potential bias related to the open-label design and lack of randomization. In addition, only responders to TCZ and patients who had no AEs, SAEs, or conditions that could lead to an unacceptable risk with continued TCZ treatment were included. Due to the length of the study, patients had a variable length of follow-up; therefore, evaluating ACR response rates using a fixed denominator over time would not give an accurate impression of response to treatment. Furthermore, the small number of patients receiving TCZ monotherapy makes comparison among patients based on background csDMARD use difficult; however, the absolute number of patients at each time point was presented to avoid potential bias.

In conclusion, in this LTE of the ACT-SURE study, TCZ as monotherapy or in combination with csDMARDs appeared to be safe, well tolerated, and efficacious over up to 132 weeks in patients with moderate to severe RA who responded to 24 weeks of TCZ.

Acknowledgments Support for third-party writing assistance for this manuscript, furnished by Nicola Gillespie, DVM, of Health Interactions, Inc., was provided by Genentech, Inc.

Funding source This study was funded by F. Hoffmann-La Roche Ltd. and Genentech, Inc.

\section{Compliance with ethical standards}

This study was approved by the institutional review board and independent ethics committee of the investigational centers. All patients provided written informed consent in accordance with the Declaration of Helsinki.

Authors' full disclosures Vivian P. Bykerk: honoraria from Amgen, Pfizer, Sanofi/Genzyme and Cipher. Andrew J. K. Östör: speaker, consulting, and/or research for BMS, Janssen, Roche, UCB, AbbVie, Pfizer, Merck, Celgene, Sanofi, Eli Lilly, Novartis. José Alvaro-Gracia: consulting fees from Roche, BMS, UCB, Lilly, MSD, and Pfizer; lecture/ speakers bureau fees from Roche, BMS, UCB, Pfizer, Lilly, MSD, and AbbVie; travel expenses from Roche, Pfizer, and UCB; grants to his institution from Roche. Karel Pavelka: honoraria as speaker and consultant for BMS, UCB, Pfizer, Roche, AbbVie, Biogen, and MSD. José Andrés Román Ivorra: advisory boards for BMS, Amgen, and Pfizer; research grants from MSD, UCB, and Roche; honoraria from Amgen, BMS, and Roche (for educational presentations); travel expenses from MSD and Pfizer. Michael T. Nurmohamed: research grants, consultation, and/or speaking fees from AbbVie, BMS, Celgene, Eli Lilly, Janssen, 
MSD, Mundipharma, Novartis, Pfizer, Roche, Sanofi, and UCB. Paris N. M. Sidiropoulos and Jenny Devenport: employees of Genentech, Inc. Yves Luder: employee of F. Hoffmann-LaRoche Ltd. Jean Sibilia: board membership and lecture/speaker fees from Roche, MSD, AbbVie, Pfizer, Actelion, BMS, Novartis, and Amgen.

Open Access This article is distributed under the terms of the Creative Commons Attribution 4.0 International License (http:// creativecommons.org/licenses/by/4.0/), which permits unrestricted use, distribution, and reproduction in any medium, provided you give appropriate credit to the original author(s) and the source, provide a link to the Creative Commons license, and indicate if changes were made.

\section{References}

1. Singh JA, Saag KG, Bridges SL Jr, Akl EA, Bannuru RR, Sullivan MC et al (2016) 2015 American College of Rheumatology guideline for the treatment of rheumatoid arthritis. Arthritis Care Res 68: $1-25$

2. Smolen JS, Landewe R, Bijlsma J, Burmester G, Chatzidionysiou $\mathrm{K}$, Dougados $\mathrm{M}$ et al (2017) EULAR recommendations for the management of rheumatoid arthritis with synthetic and biological disease-modifying antirheumatic drugs: 2016 update. Ann Rheum Dis 76:960-977

3. Bathon JM, Martin RW, Fleischmann RM, Tesser JR, Schiff MH, Keystone EC, Genovese MC, Wasko MC, Moreland LW, Weaver AL, Markenson J, Finck BK (2000) A comparison of etanercept and methotrexate in patients with early rheumatoid arthritis. N Engl J Med 343:1586-1593

4. Weinblatt ME, Keystone EC, Furst DE, Moreland LW, Weisman MH, Birbara CA, Teoh LA, Fischkoff SA, Chartash EK (2003) Adalimumab, a fully human anti-tumor necrosis factor alpha monoclonal antibody, for the treatment of rheumatoid arthritis in patients taking concomitant methotrexate: the ARMADA trial. Arthritis Rheum 48:35-45

5. Maini R, St Clair EW, Breedveld F, Furst D, Kalden J, Weisman M, Smolen J, Emery P, Harriman G, Feldmann M, Lipsky P (1999) Infliximab (chimeric anti-tumour necrosis factor alpha monoclonal antibody) versus placebo in rheumatoid arthritis patients receiving concomitant methotrexate: a randomised phase III trial. ATTRACT study group. Lancet 354:1932-1939

6. Soliman MM, Ashcroft DM, Watson KD, Lunt M, Symmons DP, Hyrich KL, British Society for Rheumatology Biologics Register (2011) Impact of concomitant use of DMARDs on the persistence with anti-TNF therapies in patients with rheumatoid arthritis: results from the British Society for Rheumatology Biologics Register. Ann Rheum Dis 70:583-589

7. Chatzidionysiou K, Emamikia S, Nam J, Ramiro S, Smolen J, van der Heijde D, Dougados M, Bijlsma J, Burmester G, Scholte M, van Vollenhoven R, Landewe R (2017) Efficacy of glucocorticoids, conventional and targeted synthetic disease-modifying antirheumatic drugs: a systematic literature review informing the 2016 update of the EULAR recommendations for the management of rheumatoid arthritis. Ann Rheum Dis 76:1102-1107

8. Chester Wasko M, Dasgupta A, Ilse Sears G, Fries JF, Ward MM (2016) Prednisone use and risk of mortality in patients with rheumatoid arthritis: moderation by use of disease-modifying antirheumatic drugs. Arthritis Care Res 68:706-710

9. Listing J, Kekow J, Manger B, Burmester GR, Pattloch D, Zink A, Strangfeld A (2015) Mortality in rheumatoid arthritis: the impact of disease activity, treatment with glucocorticoids, TNF alpha inhibitors and rituximab. Ann Rheum Dis 74:415-421
10. Smolen JS, Beaulieu A, Rubbert-Roth A, Ramos-Remus C, Rovensky J, Alecock E, Woodworth T, Alten R, OPTION Investigators (2008) Effect of interleukin-6 receptor inhibition with tocilizumab in patients with rheumatoid arthritis (OPTION study): a double-blind, placebo-controlled, randomised trial. Lancet 371: 987-997

11. Genovese MC, McKay JD, Nasonov EL, Mysler EF, da Silva NA, Alecock E, Woodworth T, Gomez-Reino JJ (2008) Interleukin-6 receptor inhibition with tocilizumab reduces disease activity in rheumatoid arthritis with inadequate response to diseasemodifying antirheumatic drugs: the tocilizumab in combination with traditional disease-modifying antirheumatic drug therapy study. Arthritis Rheum 58:2968-2980

12. Emery P, Keystone E, Tony HP, Cantagrel A, van Vollenhoven R, Sanchez A, Alecock E, Lee J, Kremer J (2008) IL-6 receptor inhibition with tocilizumab improves treatment outcomes in patients with rheumatoid arthritis refractory to anti-tumour necrosis factor biologicals: results from a 24 -week multicentre randomised placebo-controlled trial. Ann Rheum Dis 67:1516-1523

13. Jones G, Sebba A, Gu J, Lowenstein MB, Calvo A, Gomez-Reino JJ, Siri DA, Tomsic M, Alecock E, Woodworth T, Genovese MC (2010) Comparison of tocilizumab monotherapy versus methotrexate monotherapy in patients with moderate to severe rheumatoid arthritis: the AMBITION study. Ann Rheum Dis 69:88-96

14. Kremer JM, Blanco R, Brzosko M, Burgos-Vargas R, Halland AM, Vernon E, Ambs P, Fleischmann R (2011) Tocilizumab inhibits structural joint damage in rheumatoid arthritis patients with inadequate responses to methotrexate: results from the double-blind treatment phase of a randomized placebo-controlled trial of tocilizumab safety and prevention of structural joint damage at one year. Arthritis Rheum 63:609-621

15. Gabay C, Emery P, van Vollenhoven R, Dikranian A, Alten R, Pavelka K, Klearman M, Musselman D, Agarwal S, Green J, Kavanaugh A, Study Investigators ADACTA (2013) Tocilizumab monotherapy versus adalimumab monotherapy for treatment of rheumatoid arthritis (ADACTA): a randomised, double-blind, controlled phase 4 trial. Lancet 381:1541-1550

16. Dougados M, Kissel K, Sheeran T, Tak PP, Conaghan PG, Mola EM, Schett G, Amital H, Navarro-Sarabia F, Hou A, Bernasconi C, Huizinga TW (2013) Adding tocilizumab or switching to tocilizumab monotherapy in methotrexate inadequate responders: 24week symptomatic and structural results of a 2-year randomised controlled strategy trial in rheumatoid arthritis (ACT-RAY). Ann Rheum Dis 72:43-50

17. Burmester GR, Rubbert-Roth A, Cantagrel A, Hall S, Leszczynski P, Feldman D, Rangaraj MJ, Roane G, Ludivico C, Lu P, Rowell L, Bao M, Mysler EF (2014) A randomised, double-blind, parallelgroup study of the safety and efficacy of subcutaneous tocilizumab versus intravenous tocilizumab in combination with traditional disease-modifying antirheumatic drugs in patients with moderate to severe rheumatoid arthritis (SUMMACTA study). Ann Rheum Dis 73:69-74

18. Jones G, Wallace T, McIntosh MJ, Brockwell L, Gomez-Reino JJ, Sebba A (2017) Five-year efficacy and safety of tocilizumab monotherapy in patients with rheumatoid arthritis who were methotrexate- and biologic-naive or free of methotrexate for 6 months: the AMBITION study. J Rheumatol 44:142-146

19. Burmester GR, Rigby WF, van Vollenhoven RF, Kay J, RubbertRoth A, Blanco R, Kadva A, Dimonaco S (2017) Tocilizumab combination therapy or monotherapy or methotrexate monotherapy in methotrexate-naive patients with early rheumatoid arthritis: 2year clinical and radiographic results from the randomised, placebo-controlled FUNCTION trial. Ann Rheum Dis 76:1279 1284

20. Kremer JM, Rigby W, Singer NG, Birchwood C, Gill D, Reiss W, Pei J, Michalska M (2018) Sustained response following 
discontinuation of methotrexate in patients with rheumatoid arthritis treated with subcutaneous tocilizumab: results from a randomized, controlled trial. Arthritis Rheum 70:1200-1208

21. Kremer JM, Blanco R, Halland AM, Brzosko M, Burgos-Vargas R, Mela CM, Rowell L, Fleischmann RM (2016) Clinical efficacy and safety maintained up to 5 years in patients with rheumatoid arthritis treated with tocilizumab in a randomised trial. Clin Exp Rheumatol 34:625-633

22. Genovese MC, Rubbert-Roth A, Smolen JS, Kremer J, Khraishi M, Gomez-Reino J, Sebba A, Pilson R, Williams S, Van Vollenhoven R (2013) Longterm safety and efficacy of tocilizumab in patients with rheumatoid arthritis: a cumulative analysis of up to 4.6 years of exposure. J Rheumatol 40:768-780

23. Kivitz A, Wallace T, Olech E, Borofsky M, Devenport J, Pei J, Michalska M (2016) Long-term safety and efficacy of subcutaneously administered tocilizumab for adult rheumatoid arthritis: a multicenter phase $3 \mathrm{~b}$ long-term extension study. Rheumatol Ther 3:291-304

24. Kivitz A, Olech E, Borofsky MA, Zazueta B, Navarro-Sarabia F, Radominski SC, Merrill JT, Pacheco-Tena C, Pei J, Nasmyth-Miller C, Pope JE (2018) Two-year efficacy and safety of subcutaneous tocilizumab in combination with disease-modifying antirheumatic drugs including escalation to weekly dosing in rheumatoid arthritis. J Rheumatol 45:456-464

25. Bykerk VP, Ostor AJ, Alvaro-Gracia J, Pavelka K, Ivorra JA, Graninger W, Bensen W, Nurmohamed MT, Krause A, Bernasconi C, Stancati A, Sibilia J (2012) Tocilizumab in patients with active rheumatoid arthritis and inadequate responses to DMARDs and/or TNF inhibitors: a large, open-label study close to clinical practice. Ann Rheum Dis 71:1950-1954

26. Bykerk VP, Ostor AJ, Alvaro-Gracia J, Pavelka K, Ivorra JA, Graninger W, Bensen W, Nurmohamed MT, Krause A, Bernasconi C, Aassi M, Sibilia J (2015) Comparison of tocilizumab as monotherapy or with add-on disease-modifying antirheumatic drugs in patients with rheumatoid arthritis and inadequate responses to previous treatments: an open-label study close to clinical practice. Clin Rheumatol 34:563-571

27. Nishimoto N, Ito K, Takagi N (2010) Safety and efficacy profiles of tocilizumab monotherapy in Japanese patients with rheumatoid arthritis: meta-analysis of six initial trials and five long-term extensions. Mod Rheumatol 20:222-232

28. Yamamoto K, Goto H, Hirao K, Nakajima A, Origasa H, Tanaka K, Tomobe M, Totsuka K (2015) Longterm safety of tocilizumab: results from 3 years of followup postmarketing surveillance of 5573 patients with rheumatoid arthritis in Japan. J Rheumatol 42: $1368-1375$

29. Emery P, Breedveld FC, Hall S, Durez P, Chang DJ, Robertson D, Singh A, Pedersen RD, Koenig AS, Freundlich B (2008)
Comparison of methotrexate monotherapy with a combination of methotrexate and etanercept in active, early, moderate to severe rheumatoid arthritis (COMET): a randomised, double-blind, parallel treatment trial. Lancet 372:375-382

30. Maini RN, Taylor PC, Szechinski J, Pavelka K, Broll J, Balint G et al (2006) Double-blind randomized controlled clinical trial of the interleukin-6 receptor antagonist, tocilizumab, in European patients with rheumatoid arthritis who had an incomplete response to methotrexate. Arthritis Rheum 54:2817-2829

31. Fleischmann RM, Halland AM, Brzosko M, Burgos-Vargas R, Mela C, Vernon E, Kremer JM (2013) Tocilizumab inhibits structural joint damage and improves physical function in patients with rheumatoid arthritis and inadequate responses to methotrexate: LITHE study 2-year results. J Rheumatol 40:113-126

32. Harrold LR, John A, Reed GW, Haselkorn T, Karki C, Li Y, Best J, Zlotnick S, Kremer JM, Greenberg JD (2017) Impact of tocilizumab monotherapy on clinical and patient-reported quality-oflife outcomes in patients with rheumatoid arthritis. Rheumatol Ther 4:405-417

33. Kojima T, Yabe Y, Kaneko A, Takahashi N, Funahashi K, Kato D, Hanabayashi M, Asai S, Hirabara S, Asai N, Hirano Y, Hayashi M, Miyake H, Kojima M, Ishiguro N (2015) Importance of methotrexate therapy concomitant with tocilizumab treatment in achieving better clinical outcomes for rheumatoid arthritis patients with high disease activity: an observational cohort study. Rheumatology (Oxford) 54:113-120

34. Choy E, Caporali R, Xavier R, Fautrel B, Sanmarti R, Bao M, Devenport J, Petho-Schramm A (2019) Effects of concomitant glucocorticoids in TOZURA, a common-framework study programme of subcutaneous tocilizumab in rheumatoid arthritis. Rheumatology (Oxford)

35. Strehl C, Bijlsma JW, de Wit M, Boers M, Caeyers N, Cutolo M et al (2016) Defining conditions where long-term glucocorticoid treatment has an acceptably low level of harm to facilitate implementation of existing recommendations: viewpoints from an EULAR task force. Ann Rheum Dis 75:952-957

36. del Rincon I, Battafarano DF, Restrepo JF, Erikson JM, Escalante A (2014) Glucocorticoid dose thresholds associated with all-cause and cardiovascular mortality in rheumatoid arthritis. Arthritis Rheum 66:264-272

37. Youssef J, Novosad SA, Winthrop KL (2016) Infection risk and safety of corticosteroid use. Rheum Dis Clin N Am 42:157-176 ix-x

Publisher's note Springer Nature remains neutral with regard to jurisdictional claims in published maps and institutional affiliations. 